\title{
Developing a situation analysis tool to assess containment of antimicrobial resistance in South East Asia
}

\section{Manish Kakkar and colleagues discuss the development of a tool to assess how programmes tackling antimicrobial resistance in South East Asia are faring}

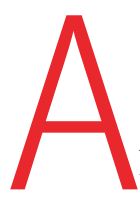

ntimicrobial resistance (AMR) is no longer defined by national or political boundaries. Isolates of Escherichia coli bearing mcr-1 were first identified in China, but shortly after were found in clinical and animal samples in the US. ${ }^{12}$ The World Health Organization and its partners have warned of the global rise of resistance against antibiotics, particularly those of "last resort." 3

Evidence shows that the main drivers of AMR are antibiotic selection pressure and transmission of resistant microbes. ${ }^{3}$ But drivers at the level of policies and systems also contribute. ${ }^{16}$ This complexity calls for a comprehensive, holistic, collaborative approach. The 68th World Health Assembly in 2015 adopted the global action plan on AMR (GAP-AMR, box 1), which was expected to translate into national action plans by May $2017 .{ }^{4}$

${ }^{17}$ National action plans should include a strategic action plan, based on a "One Health" approach, bringing together multiple sectors to combat resistance in the local context. The One Health approach provides opportunities to integrate multiple disciplines, working locally, nationally, regionally, and globally to tackle the drivers of AMR emergence.

To assist member states, WHO, the Food and Agriculture Organization of the United Nations, and the World Organisation for

\section{KEY MESSAGES}

- The situation analysis tool can assess and monitor the progress made towards implementing the national action plan for antimicrobial resistance in the member states of the South East Asia region

- A multi-stakeholder review, conducted through guided discussions, table top exercises, and site visits as needed identifies strengths, challenges, and implementation gaps

- The tool has been developed in the context of developing countries with rudimentary or non-existent programmes for the containment of antimicrobial resistance
Animal Health have developed a manual and sample templates, as well as a library of existing national action plans. ${ }^{5}$ The manual recommends performing a situation analysis before developing a national action plan. Countries differ widely in their capacity to develop a comprehensive, holistic national action plan. Of 133 countries surveyed in the worldwide situation analysis conducted by WHO, very few reported to have a comprehensive, multisectoral national action plan for containment of AMR supported by sustainable financing. ${ }^{4}$ Conducting a comprehensive situation analysis is essential for tailoring a national action plan to the setting of a particular member state, which would inform the subsequent steps of the process.

\section{SEARO tool for situation analysis}

The WHO South East Asia Regional Office (SEARO) developed a tool to conduct a system-wide analysis of AMR containment programmes. We developed indicators based on existing evidence to evaluate the progress made in each member state of the region over five years (2016-20). The tool was developed to identify vulnerabilities in the system, to identify the stage of implementation of GAP-AMR related activities, and to assess the progress made over time.

The situation analysis tool is being piloted in several countries. Here we present the tool and discuss its potential in identifying gaps in implementing the GAP-AMR, its shortcomings, and its relevance in comparison to other available tools. This will be instrumental for WHO to fulfil its obligations, in accordance with the resolution of the 68th World Health Assembly to report on the development, implementation, monitoring, and evaluation of the national action plans for the containment of AMR developed by member states. ${ }^{6}$

\section{Developing the tool}

The tool was based on a scoping literature review. We systematically searched for major frameworks for monitoring AMR in different countries. In the first stage, we searched PubMed for published, peer reviewed documents; in the second stage, we identified AMR containment programmes that had been operational and searched their websites for related documents. Finally, in the third stage, we manually searched through the bibliographies of the included documents to identify other relevant documents that we may have missed on the two previous steps. We included documents associated with national action plans, monitoring and surveillance frameworks at the national and supranational levels, and policy frameworks dealing with the drivers of and plan for the mitigation of AMR. Documents dealing with surveillance, prevention, control, and containment of AMR were obtained from national and supranational programmes, such as the AMR containment programmes in developed countries like Sweden and the US, those in developing countries like India, and supranational policy documents from bodies like the Joint Programming Initiative on AMR. We looked for further documents mentioned in the body or reference list of all documents until

Box 1: Strategic objectives of the global action plan against AMR

1. Improve awareness and understanding of antimicrobial resistance through effective communication, education, and training

2. Strengthen the knowledge and evidence base through surveillance and research

3. Reduce the incidence of infection through effective sanitation, hygiene, and infection prevention measures

4. Optimise the use of antimicrobials in human and animal health

5. Develop the economic case for sustainable investment that takes account of the needs of all countries and increase investment in new drugs, diagnostic tools, vaccines, and other interventions 
no more were found. We found a total of 42 documents -12 in the initial phase, 16 in the second stage, and14 through hand searching the included texts.

Indicators for system-wide evaluation were extracted from the documents and, after expert input, were classified into seven focus areas, each of which tackled one or more of the five strategic objectives outlined in the GAP-AMR (box 1). ${ }^{6}$ The seven focus areas were: national AMR action plan; awareness raising; national AMR surveillance; rational antimicrobial use and surveillance; antimicrobial stewardship and infection prevention and control; research and innovation; and One Health engagement (table 1).

Each indicator was graded on the extent of implementation using an incremental scale consisting of five phases based on an adaptation of the stages of implementation defined by Fixsen et al (table 2). ${ }^{7}$ The first phase - that of exploration and adoptionindicates that the process of designing an AMR containment programme has been initiated. Once the decision to implement the programme has been made, systems progress to the second phase-programme installation. The third phase-initial implementation-is one of the most challenging phases for programmes in developing countries. After the early implementation barrier is overcome and the programme is scaled up, the fourth stage-full operation-is achieved. Once the programme starts to function at the highest grade of operational efficiency, the fifth and final stage-sustainable operation-is attained.

\section{Situation analysis process and definitions}

The situation analysis process using our tool is designed to be a multi-stakeholder review, to be performed jointly by national stakeholders and WHO. National stakeholders

\begin{tabular}{|c|c|c|c|}
\hline $\begin{array}{l}\text { WHO strategic } \\
\text { objective }\end{array}$ & Focus area & Indicator & Description and best practices \\
\hline 2 & $\begin{array}{l}\text { National AMR } \\
\text { action plan (NAP) }\end{array}$ & NAP in line with GAP-AMR & $\begin{array}{l}\text { Comprehensive and multisectoral NAP implemented with a coordination body, an operational plan, a } \\
\text { monitoring system and adequate funding }\end{array}$ \\
\hline \multirow[t]{3}{*}{2} & \multirow[t]{3}{*}{$\begin{array}{l}\text { National AMR } \\
\text { surveillance } \\
\text { system }\end{array}$} & $\begin{array}{l}\text { Laboratory based AMR surveillance } \\
\text { system }\end{array}$ & $\begin{array}{l}\text { National human AMR surveillance in place and functional to monitor AMR trends accurately and timely with } \\
\text { national guidelines and regulations (minimum representative datasets, standards, definitions, methodology, } \\
\text { standards of quality implemented) }\end{array}$ \\
\hline & & Laboratory capacity strengthening & $\begin{array}{l}\text { A national network of quality assured laboratories that contributes quality and proper data to national AMR } \\
\text { surveillance }\end{array}$ \\
\hline & & Early warning system & $\begin{array}{l}\text { Early warning systems with integrated rapid response mechanisms have been incorporated in the human } \\
\text { AMR surveillance system }\end{array}$ \\
\hline \multirow[t]{6}{*}{4} & \multirow{6}{*}{$\begin{array}{l}\text { Rational use } \\
\text { and surveillance } \\
\text { (community level) }\end{array}$} & $\begin{array}{l}\text { National antimicrobials containment } \\
\text { policy }\end{array}$ & $\begin{array}{l}\text { A national AMR containment policy for control of human use of antimicrobials that is implemented and } \\
\text { enforced. AMR containment policies include vaccination policies and high coverage where appropriate }\end{array}$ \\
\hline & & National regulatory authorities & $\begin{array}{l}\text { Competent and functional regulatory authority with capacity to ensure and enforce antibiotic quality } \\
\text { standards, to take measures against substandard products, and to inspect pharmacies. }\end{array}$ \\
\hline & & $\begin{array}{l}\text { Regulation of finished antibiotic } \\
\text { products and active pharmaceutical } \\
\text { ingredients (APIs) used to manufacture } \\
\text { antibiotics for human use }\end{array}$ & $\begin{array}{l}\text { Comprehensive, multisectoral drug act is implemented nationally to regulate the production/manufacture } \\
\text { import/export of antibiotics and APIs where appropriate }\end{array}$ \\
\hline & & Regulation of supply chain & A national policy or act is in place to regulate the supply chain management of antibiotics and APIs. \\
\hline & & Regulation of pharmacies & $\begin{array}{l}\text { Presence of a regulatory system, with monitoring and evaluation frameworks, to prevent over the counter sale } \\
\text { and inappropriate sale of antibiotics and APIs }\end{array}$ \\
\hline & & $\begin{array}{l}\text { Surveillance of use and sale of } \\
\text { antimicrobials in the human sector }\end{array}$ & $\begin{array}{l}\text { Surveillance is in place and is functional to monitor sales and use in humans that produces representative } \\
\text { and quality data }\end{array}$ \\
\hline \multirow[t]{3}{*}{3} & \multirow[t]{3}{*}{$\begin{array}{l}\text { Infection } \\
\text { prevention } \\
\text { control and AMR } \\
\text { programme } \\
\text { in healthcare } \\
\text { settings }\end{array}$} & $\begin{array}{l}\text { Surveillance of healthcare associated } \\
\text { infections and antimicrobial use }\end{array}$ & $\begin{array}{l}\text { Formulation of national guidelines and policy on healthcare associated infections and antimicrobial use for } \\
\text { healthcare facilities } \\
\text { Hospitals are mandated to undertake surveillance and report healthcare associated infections as a part } \\
\text { of continuous quality control in patient care services. Surveillance data to be analysed and centralised for } \\
\text { monitoring purposes }\end{array}$ \\
\hline & & AMR stewardship programme & $\begin{array}{l}\text { Training, education, and capacity building programme. Protocols, SOPs and guidelines for IPC are available } \\
\text { based on nature and type of healthcare facility }\end{array}$ \\
\hline & & $\begin{array}{l}\text { Policies and practices and } \\
\text { governance mechanisms for the } \\
\text { programmatic control of emergence } \\
\text { of AMR in healthcare settings }\end{array}$ & $\begin{array}{l}\text { Formulation of a national policy on infection prevention and control for healthcare facilities. Implementation } \\
\text { of an AMR control programme providing guidance and best practices for implementing antimicrobial } \\
\text { stewardship and rational use of antimicrobials in each healthcare facility }\end{array}$ \\
\hline & Awareness raising & Professional education and training & $\begin{array}{l}\text { Implementation and monitoring of policy on education and training strategies for professionals, } \\
\text { paraprofessionals, and other occupational groups }\end{array}$ \\
\hline \multirow[t]{2}{*}{5} & \multirow[t]{2}{*}{$\begin{array}{l}\text { Research and } \\
\text { innovation }\end{array}$} & $\begin{array}{l}\text { Proper environment for research and } \\
\text { innovation }\end{array}$ & $\begin{array}{l}\text { Investing in development of new drugs, diagnostics, and interventions through increased research funding. } \\
\text { National policy to promote and foster innovation to combat AMR }\end{array}$ \\
\hline & & Horizon scanning & Latest updates on research agenda and advances \\
\hline \multirow[t]{5}{*}{$1-5$} & \multirow[t]{5}{*}{$\begin{array}{l}\text { One Health } \\
\text { engagement }\end{array}$} & $\begin{array}{l}\text { A national AMR containment policy } \\
\text { and regulatory framework for control } \\
\text { of animal use and their registration } \\
\text { for use }\end{array}$ & $\begin{array}{l}\text { Implementation, enforcement, and monitoring of national policy and plan on use of antimicrobials and } \\
\text { regulatory frameworks for control of animal use and their registration for use }\end{array}$ \\
\hline & & $\begin{array}{l}\text { Surveillance of use and sale of } \\
\text { antimicrobials in veterinary sectors }\end{array}$ & $\begin{array}{l}\text { The national policy and plan that identifies activities linked to use and sales of antimicrobials at national level } \\
\text { in the veterinary sector and surveillance of AMR and antimicrobial usage }\end{array}$ \\
\hline & & $\begin{array}{l}\text { Infection prevention and control in } \\
\text { the animal sector. Animal health and } \\
\text { agricultural practices }\end{array}$ & $\begin{array}{l}\text { Development and implementation of best practices on infection prevention in animal by species or } \\
\text { commodity. Surveillance and policies developed to control contamination of food abiding by the Codex } \\
\text { Alimentarius standards }\end{array}$ \\
\hline & & $\begin{array}{l}\text { Vaccination in animals to prevent and } \\
\text { reduce infection in food animals }\end{array}$ & $\begin{array}{l}\text { Development of a vaccination policy for animals, including outlining implementation strategies through } \\
\text { microplans developed at local levels }\end{array}$ \\
\hline & & Awareness in animal sector & $\begin{array}{l}\text { Strategy to engage veterinary sector in AMR prevention and control through awareness generation and } \\
\text { education in the animal health sector }\end{array}$ \\
\hline
\end{tabular}




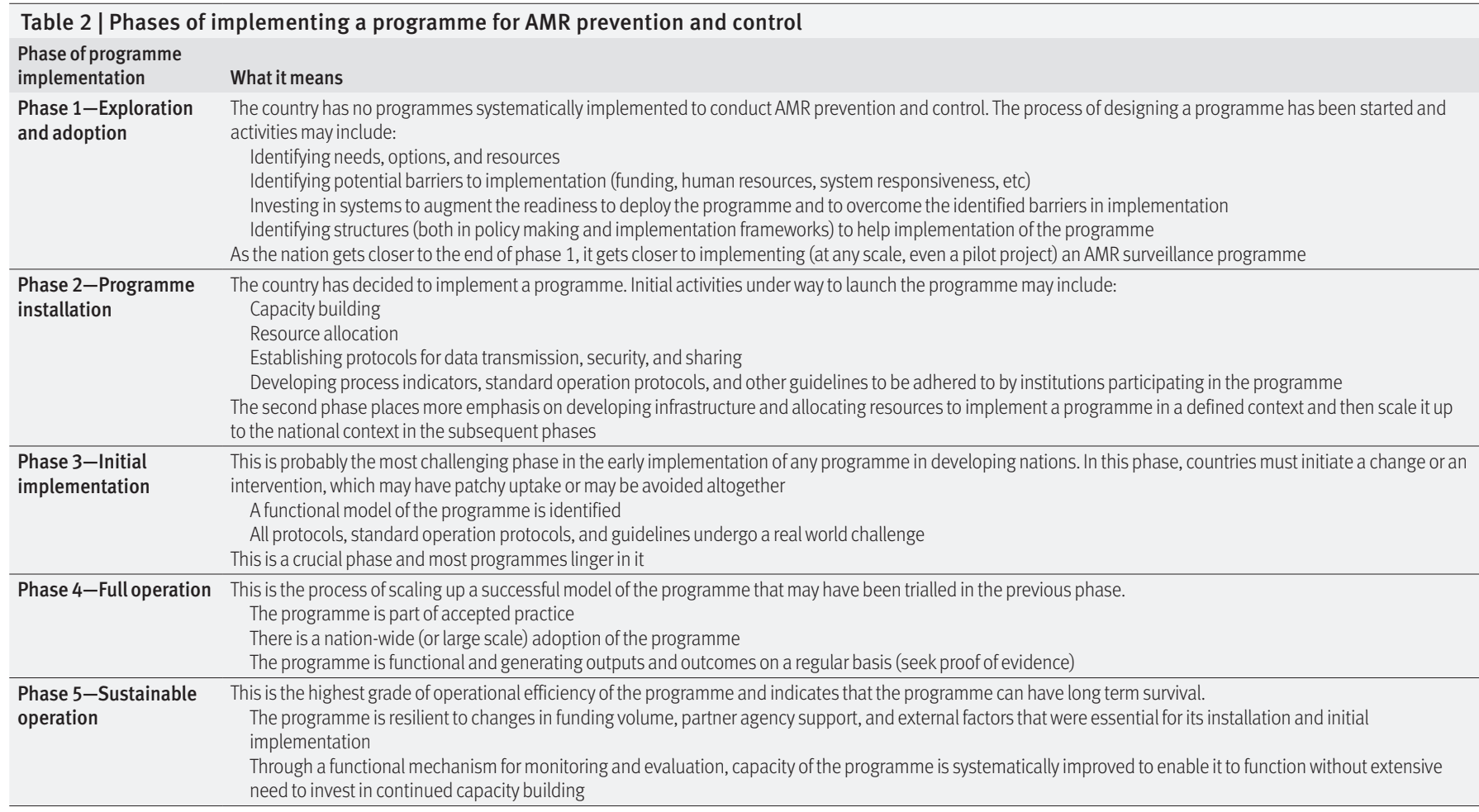

assess themselves and provide evidence and justification. WHO facilitates the process and helps reach a consensus on the grading through guided discussions. The guided discussion technique ${ }^{89}$ is used to elicit dialogue and exchanges between reviewers and stakeholders. Core questions trigger discussions on each focus area. We defined a functional system as a system that shows sound procedures, interdepartmental interactions, leadership, governance and funding capacity, and outputs (reports, decisions translated into actions). ${ }^{10}$

Based on the outcome of the multistakeholder review, a thematic situation analysis might be conducted. A combination of the review for capacity and that for functionality describe at which stage the AMR containment programme is positioned for each focus area.

Results of the process can be summarised in the form of an analysis of strengths and challenges, mapped using the phases attained by the indicators for each strategic objective. Indicators in the first two phases of implementation are considered to contribute to challenges and vulnerability of the system, whereas those in the three higher phases are considered to be strengths of the system.

\section{Existing tools and approaches to monitor AMR}

Two monitoring and evaluation frameworks have been widely implemented globally for assessment of national AMR containment programmes-the WHO rapid assessment tool for country situation analysis and the international health regulations joint external evaluation tool.
The WHO rapid assessment tool was used to determine the extent to which effective practices and structures to tackle AMR were already in place and where gaps remained. ${ }^{4}$ A total of 133 of the 194 WHO member states provided information. The tool covered the six objectives of the 2011 WHO strategy as a questionnaire with largely close ended questions; it was submitted to national health authorities for self assessment and reporting, which may be biased and of limited credibility. The WHO rapid assessment tool has a limited scope to provide insights on how operational an AMR containment programme is. Furthermore, it does not adequately assess engagement with and response from One Health and related mechanisms that are important for AMR prevention and control.

More recently AMR has been acknowledged as a threat to global economic stability and security. ${ }^{11}$ The Global Health Security Agenda-a partnership between countries to "prevent, detect, and respond to biological threats"was launched in 2013 and included AMR as one of the 11 priorities for global action. ${ }^{12}{ }^{13}$ Building on this agenda ${ }^{12}$ and other assessments, WHO developed the joint external evaluation tool ${ }^{1314}$ to foster compliance with the core capacity requirements of the international health regulations. AMR is part of a larger set of public health issues concerning global health. ${ }^{15}$ Despite having functional indicators that might assess improvements in programme implementation over time, the joint external evaluation tool fails to capture the complexity of AMR containment as detailed in the GAP-AMR. Many aspects of the strategic objectives of the global action plan are missing, including research and innovation and capacity strengthening. It does not capture the multisectoral essence and has minimal alignment with GAP-AMR. The One Health approach is measured in a broad way so that multisectoral governance over AMR containment is diluted. Stewardship activities are bundled together in one category. Although the joint external evaluation tool captures key elements of system-wide functionality regarding AMR containment programmes, progress against the threat of AMR requires comprehensive and concrete metrics that can be monitored and measured efficiently.

\section{SEARO tool: Strengths, limitations, and recommendations}

AMR is an ongoing silent epidemic across the world, which many countries have limited capacity to detect. Given the limited resources, competing priorities and political challenges could derail the implementation goals of the national action plan. Enabling all countries to measure progress towards sustained operations of the AMR containment programme is, therefore, essential.

The SEARO tool is organised around the development and implementation of national action plans (table 3 ). Through an extensive set of indicators, the tool provides information on comprehensive governance, policy, and systems analysis and can be applied at the community as 


\begin{tabular}{|c|c|c|c|c|c|}
\hline \multirow[t]{2}{*}{ Indicators } & \multicolumn{5}{|l|}{ Phases } \\
\hline & Exploration and adoption & Programme installation & Initial implementation & Full operation & Sustainable operation \\
\hline \multicolumn{6}{|l|}{ 1. National AMR action plan } \\
\hline $\begin{array}{l}\text { NAP in line with } \\
\text { GAP-AMR }\end{array}$ & $\begin{array}{l}\text { No action plan or no } \\
\text { national multisectoral } \\
\text { committee or AMR } \\
\text { committee established but } \\
\text { involving one ministry }\end{array}$ & $\begin{array}{l}\text { AMR working group } \\
\text { established and national } \\
\text { action plan under way }\end{array}$ & $\begin{array}{l}\text { Action plan aligned with } \\
\text { GAP including operational } \\
\text { plan with defined activities } \\
\text { and respective budget } \\
\text { available }\end{array}$ & $\begin{array}{l}\text { Action plan includes } \\
\text { operational plan being } \\
\text { rolled out and scaled up } \\
\text { with defined activities and } \\
\text { respective budget }\end{array}$ & $\begin{array}{l}\text { Action plan includes } \\
\text { operational plan being } \\
\text { rolled out and scaled up } \\
\text { with defined activities and } \\
\text { respective budget }\end{array}$ \\
\hline \multicolumn{6}{|l|}{ 2. Awareness raising } \\
\hline $\begin{array}{l}\text { Awareness campaigns to } \\
\text { the public }\end{array}$ & $\begin{array}{l}\text { Government not involved in } \\
\text { awareness raising activities } \\
\text { on antibiotic resistance }\end{array}$ & $\begin{array}{l}\text { Some government led } \\
\text { activities in parts of the } \\
\text { country to raise awareness } \\
\text { about AMR and actions to } \\
\text { tackle it }\end{array}$ & $\begin{array}{l}\text { Nationwide, government } \\
\text { led antibiotic awareness } \\
\text { campaign targeting } \\
\text { the general public or } \\
\text { professionals }\end{array}$ & $\begin{array}{l}\text { Nationwide, government } \\
\text { led antibiotic awareness } \\
\text { campaign targeting public } \\
\text { and professionals }\end{array}$ & $\begin{array}{l}\text { Assessing effects of } \\
\text { government led awareness } \\
\text { campaigns on behaviour } \\
\text { changes in public and } \\
\text { professionals }\end{array}$ \\
\hline $\begin{array}{l}\text { Education and training } \\
\text { strategies for professionals }\end{array}$ & No policy or strategy & $\begin{array}{l}\text { Relevant policies developed } \\
\text { but ad hoc training courses } \\
\text { in some disciplines }\end{array}$ & $\begin{array}{l}\text { AMR included in some } \\
\text { preservice training or } \\
\text { special courses or both } \\
\text { OR } \\
\text { Continuous professional } \\
\text { development and regular } \\
\text { audit of learning }\end{array}$ & $\begin{array}{l}\text { AMR included in some } \\
\text { preservice training or some } \\
\text { special courses or both } \\
\text { AND } \\
\text { Continuous professional } \\
\text { development and regular } \\
\text { audit of learning }\end{array}$ & $\begin{array}{l}\text { AMR included in preservice } \\
\text { training for all relevant } \\
\text { cadres } \\
\text { Regular continuing } \\
\text { professional development }\end{array}$ \\
\hline \multicolumn{6}{|c|}{ 3. National AMR surveillance system } \\
\hline $\begin{array}{l}\text { National human AMR } \\
\text { surveillance }\end{array}$ & $\begin{array}{l}\text { No capacity for AMR } \\
\text { laboratory or limited } \\
\text { reporting or both, or no } \\
\text { surveillance guidelines }\end{array}$ & $\begin{array}{l}\text { Guidelines developed but } \\
\text { not fully implemented. } \\
\text { Limited quality data and } \\
\text { analysis and not fully } \\
\text { representative of country }\end{array}$ & $\begin{array}{l}\text { Standardised national AMR } \\
\text { surveillance in place and } \\
\text { representative of country } \\
\text { but limited number of } \\
\text { operational sites }\end{array}$ & $\begin{array}{l}\text { Surveillance in place and } \\
\text { functional to monitor AMR } \\
\text { trends accurately and timely } \\
\text { but no contributing data } \\
\text { to GLASS }\end{array}$ & $\begin{array}{l}\text { National AMR surveillance } \\
\text { regularly assessed and } \\
\text { adjusted; and contributing } \\
\text { to GLASS }\end{array}$ \\
\hline $\begin{array}{l}\text { National laboratory network } \\
\text { strengthening }\end{array}$ & $\begin{array}{l}\text { No national network } \\
\text { developed }\end{array}$ & $\begin{array}{l}\text { A national network with } \\
\text { testing according to the } \\
\text { international standards is } \\
\text { planned }\end{array}$ & $\begin{array}{l}\text { A national reference } \\
\text { laboratoryis identified, } \\
\text { and quality assured } \\
\text { laboratory networks have } \\
\text { been developed only at } \\
\text { few surveillance sites }\end{array}$ & $\begin{array}{l}\text { A national network of EQA } \\
\text { health laboratories has } \\
\text { been developed in most or } \\
\text { all surveillance sites }\end{array}$ & $\begin{array}{l}\text { A laboratory network is } \\
\text { established, EQA measures } \\
\text { are in place, and the } \\
\text { reference laboratory has } \\
\text { demonstrated capacity for } \\
\text { research }\end{array}$ \\
\hline Early warning systems & $\begin{array}{l}\text { No system in place or } \\
\text { planned }\end{array}$ & $\begin{array}{l}\text { System planned, in keeping } \\
\text { with international standards }\end{array}$ & $\begin{array}{l}\text { System is implemented } \\
\text { in pilot mode,or is } \\
\text { implemented on a national } \\
\text { scale but not fully functional } \\
\text { (not sensitive to reportable } \\
\text { events) }\end{array}$ & $\begin{array}{l}\text { Demonstrated functional } \\
\text { capacity: data centralised } \\
\text { and analysed with reports }\end{array}$ & $\begin{array}{l}\text { Demonstrated functional } \\
\text { capacity and proof of } \\
\text { response from detection }\end{array}$ \\
\hline \multicolumn{6}{|c|}{ 4. Rational use of antimicrobials and surveillance of use and sale (community based) } \\
\hline $\begin{array}{l}\text { A national AMR containment } \\
\text { policy for control of human } \\
\text { use of antimicrobials; AMR } \\
\text { stewardship (AMS) }\end{array}$ & $\begin{array}{l}\text { No or weak national policy } \\
\text { and plan, regulations for } \\
\text { antimicrobial use, and } \\
\text { availability }\end{array}$ & $\begin{array}{l}\text { National AMS } \\
\text { programme(AMSP) planned } \\
\text { and under development }\end{array}$ & $\begin{array}{l}\text { AMSP is developed, } \\
\text { including tools to } \\
\text { implement and monitor } \\
\text { AMS progress and impact }\end{array}$ & $\begin{array}{l}\text { AMSP implemented by } \\
\text { relevant institutions. } \\
\text { Regulations for } \\
\text { antimicrobial use and } \\
\text { availability are implemented } \\
\text { in limited capacity }\end{array}$ & $\begin{array}{l}\text { A national AMSP for } \\
\text { control of human use of } \\
\text { antimicrobials has been } \\
\text { implemented and enforced } \\
\text { for more than } 2 \text { years }\end{array}$ \\
\hline $\begin{array}{l}\text { National Regulatory } \\
\text { Authorities (NRA) or Drug } \\
\text { Regulatory Authorities } \\
\text { (DRA) }\end{array}$ & $\begin{array}{l}\text { No official NRA or DRA or } \\
\text { those existing have limited } \\
\text { capacity }\end{array}$ & $\begin{array}{l}\text { NRA or DRA with limited } \\
\text { capacity but strategic } \\
\text { planning in place for } \\
\text { capacity building and } \\
\text { appropriate budgeting }\end{array}$ & $\begin{array}{l}\text { NRA or DRA system set up } \\
\text { for oversight but not fully } \\
\text { functional }\end{array}$ & $\begin{array}{l}\text { Tools for quality assurance } \\
\text { and registration of } \\
\text { antibiotics in place and } \\
\text { inspection implemented } \\
\text { but limited capacity for } \\
\text { enforcement of policies and } \\
\text { regulation }\end{array}$ & $\begin{array}{l}\text { Competent and functional } \\
\text { NRA or DRA with capacity to } \\
\text { ensure or enforce antibiotic } \\
\text { quality standards,to } \\
\text { take measures against } \\
\text { substandard products and } \\
\text { to inspect pharmacies }\end{array}$ \\
\hline $\begin{array}{l}\text { Surveillance of antimicrobial } \\
\text { use and sales in humans }\end{array}$ & $\begin{array}{l}\text { No guidelines for } \\
\text { surveillance of use or sales } \\
\text { of antimicrobials or both }\end{array}$ & $\begin{array}{l}\text { National policy and plan } \\
\text { on surveillance of use } \\
\text { of antimicrobials under } \\
\text { development or developed } \\
\text { and approved but not } \\
\text { implemented (surveillance } \\
\text { in individual facilities and } \\
\text { national level sales) }\end{array}$ & $\begin{array}{l}\text { Monitoring sales of } \\
\text { antimicrobials at national } \\
\text { level not implemented. } \\
\text { Monitoring of use is } \\
\text { irregular and limited to } \\
\text { few facilities that are not } \\
\text { representative }\end{array}$ & $\begin{array}{l}\text { National sales data are } \\
\text { collected on a regular basis } \\
\text { (every 1-2 years). Data are } \\
\text { collected from a small and } \\
\text { not representative sample } \\
\text { of individual healthcare } \\
\text { facilities. No established } \\
\text { analysis with national } \\
\text { AMR laboratory based } \\
\text { surveillance }\end{array}$ & $\begin{array}{l}\text { National sales data are } \\
\text { collected on a regular basis } \\
\text { (every } 1 \text {-2 years). AMU } \\
\text { surveys are conducted in } \\
\text { a representative sample of } \\
\text { facilities and translated into } \\
\text { actions. Links with national } \\
\text { AMR surveillance data are } \\
\text { analysed and reported }\end{array}$ \\
\hline $\begin{array}{l}\text { Regulation of finished } \\
\text { antibiotic products and APIs }\end{array}$ & $\begin{array}{l}\text { No official regulation on } \\
\text { import, export, production, } \\
\text { distribution, and use of } \\
\text { finished antibiotic products } \\
\text { and APIs or those existing } \\
\text { have limited capacity }\end{array}$ & $\begin{array}{l}\text { Regulation with limited } \\
\text { capacity but strategic } \\
\text { planning in place for } \\
\text { capacity building and } \\
\text { appropriate budgeting }\end{array}$ & $\begin{array}{l}\text { Regulatory authority and } \\
\text { system set up for oversight } \\
\text { with a limited functional } \\
\text { capability }\end{array}$ & $\begin{array}{l}\text { Regulatory authority } \\
\text { and system in place and } \\
\text { inspection implemented } \\
\text { but with limited capacity for } \\
\text { enforcement of policies and } \\
\text { regulation }\end{array}$ & $\begin{array}{l}\text { Regulatory authority and } \\
\text { system in place and are fully } \\
\text { and effectively implemented }\end{array}$ \\
\hline $\begin{array}{l}\text { Regulation of pharmacies } \\
\text { on over the counter sale } \\
\text { and inappropriate sale of } \\
\text { antibiotics and APIs }\end{array}$ & $\begin{array}{l}\text { No official regulation on } \\
\text { over the counter sale } \\
\text { and inappropriate sale of } \\
\text { antibiotics and APIs }\end{array}$ & $\begin{array}{l}\text { Regulation with limited } \\
\text { capacity but strategic } \\
\text { planning in place for } \\
\text { capacity building and } \\
\text { appropriate budgeting }\end{array}$ & $\begin{array}{l}\text { Regulatory authority and } \\
\text { system set up for oversight } \\
\text { with a limited functional } \\
\text { capability }\end{array}$ & $\begin{array}{l}\text { Regulatory authority } \\
\text { and system in place and } \\
\text { inspection implemented } \\
\text { but with limited capacity for } \\
\text { enforcement of regulation }\end{array}$ & $\begin{array}{l}\text { Regulatory authority and } \\
\text { system in place and are fully } \\
\text { and effectively implemented }\end{array}$ \\
\hline
\end{tabular}




\begin{tabular}{|c|c|c|c|c|c|}
\hline \multirow{2}{*}{ Indicators } & \multicolumn{5}{|l|}{ Phases } \\
\hline & Exploration and adoption & Programme installation & Initial implementation & Full operation & Sustainable operation \\
\hline \multicolumn{6}{|c|}{ 5. Infection prevention control and AMR stewardship programme } \\
\hline $\begin{array}{l}\text { AMR stewardship } \\
\text { programme in healthcare } \\
\text { setting }\end{array}$ & $\begin{array}{l}\text { No national AMR } \\
\text { stewardship policy or } \\
\text { operational plan is available } \\
\text { or approved }\end{array}$ & $\begin{array}{l}\text { A national IPC or AMR } \\
\text { policy or operational plan is } \\
\text { available but weak. SOPs, } \\
\text { guidelines, and protocols } \\
\text { not available to all hospitals } \\
\text { (limited updates) }\end{array}$ & $\begin{array}{l}\text { National IPC, AMR } \\
\text { aligned IPC, or AMR plans } \\
\text { implemented in limited } \\
\text { number of healthcare } \\
\text { settings }\end{array}$ & $\begin{array}{l}\text { National IPC, AMR aligned } \\
\text { IPC, or AMR plans are } \\
\text { implemented in about all } \\
\text { healthcare settings }\end{array}$ & $\begin{array}{l}\text { IPC or AMR measures are } \\
\text { widely implemented and } \\
\text { regularly evaluated and } \\
\text { shared }\end{array}$ \\
\hline $\begin{array}{l}\text { IPC programme in } \\
\text { healthcare setting }\end{array}$ & $\begin{array}{l}\text { No national IPC policy, } \\
\text { guidelines, or action } \\
\text { plans to mandate IPC in } \\
\text { healthcare settings }\end{array}$ & $\begin{array}{l}\text { A national capacity building } \\
\text { programme, or operational } \\
\text { plan, is developed. SOPs, } \\
\text { guidelines, and protocols } \\
\text { are developed and available } \\
\text { but not implemented }\end{array}$ & $\begin{array}{l}\text { IPC programme and } \\
\text { capacity building plans are } \\
\text { implemented in selected } \\
\text { healthcare settings }\end{array}$ & $\begin{array}{l}\text { IPC programme and } \\
\text { capacity building plans } \\
\text { implemented nationwide }\end{array}$ & $\begin{array}{l}\text { IPC capacity building and } \\
\text { programme effectiveness } \\
\text { are regularly evaluated and } \\
\text { shared }\end{array}$ \\
\hline $\begin{array}{l}\text { National } \mathrm{HAl} \text { and related } \\
\text { AMR surveillance }\end{array}$ & $\begin{array}{l}\text { No policies, limited national } \\
\text { plan and guidelines to } \\
\text { mandate hospitals for HAI } \\
\text { surveillance }\end{array}$ & $\begin{array}{l}\text { Few public and private } \\
\text { facilities have HAl } \\
\text { surveillance but data not } \\
\text { centralised at national level }\end{array}$ & $\begin{array}{l}\text { Few public and private } \\
\text { facilities have HAl } \\
\text { surveillance and share data } \\
\text { at national level }\end{array}$ & $\begin{array}{l}\text { Centralised data on HAI } \\
\text { from several hospitals but } \\
\text { with limited capacity for } \\
\text { data analysis and detection }\end{array}$ & $\begin{array}{l}\text { Monitoring and response } \\
\text { frameworks established } \\
\text { to identify critical HAl } \\
\text { events, especially related to } \\
\text { emergence of AMR indicator } \\
\text { bacteria against critical } \\
\text { drugs }\end{array}$ \\
\hline $\begin{array}{l}\text { Sanitation, hygiene, and } \\
\text { vaccination }\end{array}$ & $\begin{array}{l}\text { No formal campaign on } \\
\text { sanitation, hygiene, and } \\
\text { vaccination }\end{array}$ & $\begin{array}{l}\text { Formal campaign to } \\
\text { enhance sanitation, } \\
\text { hygiene, and vaccination } \\
\text { being developed }\end{array}$ & $\begin{array}{l}\text { Formal campaign to } \\
\text { enhance sanitation, } \\
\text { hygiene, and vaccination is } \\
\text { implemented in small scale }\end{array}$ & $\begin{array}{l}\text { Formal campaign to } \\
\text { enhance sanitation, } \\
\text { hygiene, and vaccination is } \\
\text { implemented in large scale }\end{array}$ & $\begin{array}{l}\text { Formal campaign to } \\
\text { enhance sanitation, } \\
\text { hygiene, and vaccination } \\
\text { is implemented in large } \\
\text { scale and associated with a } \\
\text { monitoring and evaluation } \\
\text { system }\end{array}$ \\
\hline \multicolumn{6}{|l|}{ 6. Research and innovation } \\
\hline $\begin{array}{l}\text { Research and development } \\
\text { and innovation on } \\
\text { AMR prevention and } \\
\text { containment (plus research } \\
\text { funding) }\end{array}$ & $\begin{array}{l}\text { No policies fostering } \\
\text { research environment } \\
\text { although capacity exists for } \\
\text { research }\end{array}$ & $\begin{array}{l}\text { Policies planned and } \\
\text { existing structure has a } \\
\text { plan to foster research and } \\
\text { innovation on AMR }\end{array}$ & $\begin{array}{l}\text { Presence of policies and } \\
\text { investments to foster } \\
\text { research and innovation } \\
\text { on AMR }\end{array}$ & $\begin{array}{l}\text { Research consortium } \\
\text { and dynamic research } \\
\text { programme are ongoing led } \\
\text { by government agenda }\end{array}$ & $\begin{array}{l}\text { Government led research } \\
\text { outputs related to AMR } \\
\text { global research agenda }\end{array}$ \\
\hline \multicolumn{6}{|l|}{ 7. One Health engagement } \\
\hline $\begin{array}{l}\text { A national AMR containment } \\
\text { policy and regulatory } \\
\text { framework for control } \\
\text { of animal use and their } \\
\text { registration for use }\end{array}$ & $\begin{array}{l}\text { No national policy or plan to } \\
\text { reduce use of antibiotics }\end{array}$ & $\begin{array}{l}\text { National policy and plan } \\
\text { on use of antimicrobials } \\
\text { developed and approved } \\
\text { or regulatory framework } \\
\text { for control of animal use } \\
\text { and their registration for } \\
\text { use is developed but not } \\
\text { implemented }\end{array}$ & $\begin{array}{l}\text { Implementation of policy } \\
\text { and plan but limited } \\
\text { capacity for monitoring use } \\
\text { and quality of drugs }\end{array}$ & $\begin{array}{l}\text { Policy and plan } \\
\text { implemented with some } \\
\text { capacity for monitoring } \\
\text { but limited capacity for } \\
\text { enforcement }\end{array}$ & $\begin{array}{l}\text { Policy and plan } \\
\text { implemented with proper } \\
\text { capacity for monitoring } \\
\text { and increased capacity for } \\
\text { enforcement }\end{array}$ \\
\hline $\begin{array}{l}\text { National surveillance of } \\
\text { AMR and use and sales of } \\
\text { antimicrobials at national } \\
\text { level in the veterinary sector }\end{array}$ & $\begin{array}{l}\text { No or weak national policy } \\
\text { and guidelines }\end{array}$ & $\begin{array}{l}\text { Limited capacity for } \\
\text { surveillance of sales, AMR, } \\
\text { or AMU }\end{array}$ & $\begin{array}{l}\text { Some capacity and data } \\
\text { generated from sales, AMR } \\
\text { or AMU }\end{array}$ & $\begin{array}{l}\text { Some comparative analysis } \\
\text { of surveillance data } \\
\text { between AMR and AMU }\end{array}$ & $\begin{array}{l}\text { Comprehensive approach } \\
\text { of surveillance with } \\
\text { coordinated analysis } \\
\text { between humans and } \\
\text { animals }\end{array}$ \\
\hline $\begin{array}{l}\text { Infection prevention and } \\
\text { control in the animal sector }\end{array}$ & $\begin{array}{l}\text { No policy and national } \\
\text { guidelines developed } \\
\text { for biosecurity to reduce } \\
\text { infection rates in food and } \\
\text { both large producers and } \\
\text { small holders }\end{array}$ & $\begin{array}{l}\text { Policies and national } \\
\text { guidelines in line with } \\
\text { international standards } \\
\text { planned including } \\
\text { vaccination policy and } \\
\text { Codex Alimentarius } \\
\text { standards }\end{array}$ & $\begin{array}{l}\text { Limited implementation, } \\
\text { particularly in large } \\
\text { producers }\end{array}$ & Full implementation & $\begin{array}{l}\text { Fully implemented in } \\
\text { multiple areas with a } \\
\text { monitoring frameworkin } \\
\text { place }\end{array}$ \\
\hline $\begin{array}{l}\text { AMR awareness generation } \\
\text { and education in the animal } \\
\text { sector }\end{array}$ & $\begin{array}{l}\text { No policies or strategies } \\
\text { exist or are only planned }\end{array}$ & $\begin{array}{l}\text { Policies or strategies } \\
\text { developed }\end{array}$ & $\begin{array}{l}\text { AMR in some pre- service } \\
\text { training or special courses } \\
\text { or both } \\
\text { OR } \\
\text { Continuous professional } \\
\text { development and regular } \\
\text { audit of learning }\end{array}$ & $\begin{array}{l}\text { AMR in some pre- service } \\
\text { training or special courses } \\
\text { or both } \\
\text { AND } \\
\text { Continuous professional } \\
\text { development and regular } \\
\text { audit of learning }\end{array}$ & $\begin{array}{l}\text { Effect of education } \\
\text { programme on behaviour } \\
\text { changes is assessed }\end{array}$ \\
\hline
\end{tabular}

AMR=antimicrobial resistance; $\mathrm{AMU}=$ antimicrobial usage; $\mathrm{API}=$ active pharmaceutical ingredient; $\mathrm{EQA}=$ external quality assessment; GAP-AMR=global action plan on antimicrobial resistance; GLASS=global antimicrobial resistance surveillance system; $\mathrm{HAl}=$ hospital acquired infections; IPC=infection prevention and control; NAP=national action plan; SOP=standard operating procedures.

well as the systems level. It provides a combination of functionality and capacity assessment and can be used repeatedly over time to assess progress. It focuses on areas where active participation, political will, and stakeholder engagement are crucial to success, thereby giving a glimpse into the extent of involvement of the political and governance machinery in tackling AMR concerns. Additionally, it emphasises engagement with One Health in a trans-sectoral sense, at the policy implementation level, which is critical given that antimicrobial use in the veterinary sector is a major determinant of the emergence of AMR.
The incremental phases through which the indicators progress are also indicative of systems building over time, fostering ownership, collaboration, and transparency. Compared with other assessment tools, the language used to describe the different stages of development encourages countries 
and allows them to benchmark their progress.

Moreover, we provide a clear direction to AMR containment in terms of best practices, best policies, and system development including a roadmap in the form of an infographic (see data supplement on bmj. com). In the last phase-sustainable operation-components of sustainability are clearly implemented with secured funding and a monitoring and evaluation system that documents findings and subsequent changes made for improvement.

The SEARO tool is limited by its inability to assess the quality of implementation of framed policies and programmes, as it only assesses the extent to which the programmes are implemented. Considering that the countries currently using the tool have no or rudimentary programmes for AMR containment, however, assuring implementation is the essential first step. Once most countries reach phase 4-full operation-further steps could be added between phases 4 and 5 to monitor quality.

We have piloted the tool in three countries-Indonesia, Maldives, and Sri Lanka-and found that these countries appreciated the tailored tool and the one-to-one assistance we provided, which identified problems pertinent to the countries, many of which have systems gaps and relatively rudimentary programmes for containment of AMR that need extensive support and strengthening.

Traditionally, AMR surveillance has not been included in the health related priorities of countries in South East Asia. Consequently, in keeping with the GAPAMR, tools that focus on building and strengthening systems are critical, rather than tools that assess the quality of programme implementation. Countries should focus on adopting pragmatic and relevant approaches that consider the regional peculiarities that drive the emergence and progress of AMR. Tools should not focus on inter-country comparisons but rather allow individual member states to prioritise and formally document the most urgent needs of individual nations to enhance implementation of AMR surveillance programmes. The SEARO tool is likely to fulfil these objectives by providing individual member states with an understanding of the current status of AMR surveillance implementation; this, in turn, should provide scaffolding for a customised national action plan that is driven by national priorities. WHO's regional and country offices are committed to supporting administration of the tool to ensure that AMR is tackled successfully.

Contributors and sources: All authors participated in the development of the manuscript. SV

conceptualised the article and, in discussion with AS and MK, drew up the outline. MK was responsible for conducting the review and developing the tool. He wrote the first draft of the article. AS and SV reviewed the tool, including pilot testing, and provided inputs in subsequent drafts based on pilot experiences. All authors participated in revising the drafts and approving the final. SV is the guarantor.

Funding: This work was commissioned by the WHO Regional Office of South East Asia using the UK government's Fleming Fund. The authors alone are responsible for the views expressed in this article, which does not necessarily represent the views, decisions, or policies of the institutions with which the authors are affiliated.

Competing interests: The authors have read and understood BMJ policy on declaration of interests and declare no competing interests.

Provenance and peer review: Commissioned; externally peer reviewed.

This article is one of a series commissioned by The $B M$ J based on an idea from WHO SEARO. The BMI retained full editorial control over external peer review, editing, and publication. Open access fees are funded by the WHO SEARO.

Manish Kakkar, WHO consultant

Anuj Sharma, antimicrobial resistance focal point

Sirenda Vong, regional technical lead

World Health Organization, Office of South East Asia region, New Delhi, India

Correspondence to: SVong vongs@who.int

1 Liu Y-Y, Wang Y, Walsh TR. Emergence of plasmidmediated colistin resistance mechanism MCR1 in animals and human beings in China: a microbiological and molecular biological study. Lancet Infect Dis 2016;16:161-8. doi:10.1016/ S1473-3099(15)00424-7

2 McGann P. Snesrud E, Maybank R. Escherichia coli Harboring mcr-1 and blaCTX-M on a Novel IncF
Plasmid: First Report of mcr-1 in the United States. Antimicrob Agents Chemother 2016;60:4420-1.

3 World Health Organization. Emergence and spread of antimicrobial resistance. Drug resistance. 2016http://www.who.int/drugresistance/AMR_ Emergence Spread/en/

4 World Health Organization. Worldwide country situation analysis: response to antimicrobial resistance. 2015. http://www.who.int/ drugresistance/en/

5 World Health Organization. National action plans (NAP). 2016

6 World Health Organization. Global action plan on antimicrobial resistance. 2015. http://www.who.int/ antimicrobial-resistance/publications/global-actionplan/en/

7 Fixsen DL, Naoom SF, Blase KA, Friedman RM, Wallace F. Implementation Research: A Synthesis of the Literature. University of South Florida, Louis de la Parte Florida Mental Health Institute, The National Implementation Research Network, 2005.

8 Ulin PR, Robinson ET, Tolley EE, eds. Qualitative methods in public health. A field guide for applied research. 1st ed. Jossey-Bass, 2005.

9 Lane Community College. Guided discussion. http://www.lanecc.edu/sites/default/files/ aviationacademy/05-guideddiscussion.doc

10 Vong S, Samuel R, Gould P. Assessment of Ebola virus disease preparedness in the WHO South-East Asia Region. Bull World Health Organ 2016;94: 913-24. doi:10.2471/BLT.16.174441

11 O'Neill J. Antimicrobial resistance: tackling a crisis for the health and wealth of nations. 2014. https:// amr-review.org/sites/default/files/AMRReviewPaperTacklingacrisisforthehealthandwealthofnations_1.pdf.

12 Global Health Security Agenda. Action Packages. 2014 http://www.cdc.gov/globalhealth/ healthprotection/ghs/pdf/ghsa-action-packages_24 september-2014.pdf

13 IHR Monitoring and Evaluation Framework. Joint external evaluation tool. International Health Regulations (2005). 2016.http://apps.who.int/iris/ handle/10665/204368

14 World Health Organization. Technical consultation on monitoring and evaluation of functional core capacity for implementing the International Health Regulations (2005) Key points and recommendations2005www.who.int/about/ licensing/copyright_form/en/index.html

15 World Health Organization. International Health Regulations (2005). Areas of work for implementation. 2007http://www.who.int/ihr/ finalversion9Nov07.pdf

16 Chereau F, Opatowski L, Tourdjman M, Vong S. Risk assessment for antibiotic resistance in South East Asia. BMJ 2017;358:j3393.

17 World Health Organization. Global action plan on antimicrobial resistance. 2015 http://www.who.int/ antimicrobial-resistance/publications/global-actionplan/en/.

Cite this as: $B M / 2017 ; 358: j 3760$

http://dx.doi.org/10.1136/bmj.j3760

This an open access article distributed under the terms of the Creative Commons Attribution-non-commercial IGO License (https:// creativecommons.org/licenses/by-nc/3.0/igo/), which permits use, distribution, and reproduction for non-commercial purposes in any medium, provided the original work is properly cited. In any reproduction of this article there should not be any suggestion that WHO or this article endorse any specific organisation or products. The use of the WHO logo is not permitted. This notice should be preserved along with the article's original URL. 